\author{
Александра М. МАРКОВИЋ* \\ Институт за српски језик САНУ \\ Београд
}

Оригинални научни рад

Примљен: 23. 01. 2019.

Прихваћен: 14. 02. 2019.

\title{
О НЕКИМ ПИТАЮИМА ПАДЕЖНЕ СИНОНИМИЈЕ У СРПСКОМ ЈЕЗИКУ ИЗ УГЛА КОГНИТИВНЕ ЛИНГВИСТИКЕ ${ }^{* *}$
}

\begin{abstract}
Предмет рада је непотпуна падежна синонимија сагледана из угла когнитивне лингвистике. Наш циљ није попис и опис одређене групе непотпуних падежних синонима, већ настојање да утврдимо шта је то што доводи до падежне синонимије (квалитативног генитива и инструментала, с једне стране, и квалитативног генитива и локатива, с друге). Трагали смо и за одговором на питање због чега су у неким случајевима два падежа синонимна, док у другим, наоко сличним случајевима, нису. Да бисмо одговорили на то питање, морали смо да загледамо испод површине језичке форме и да се запитамо које когнитивне појаве леже у основи падежне синонимије. Падеже смо сагледали кроз призму сликовних схема.

Кључне речи: непотпуна падежна синонимија, падежи и ППК с квалитативним значењем, сликовне схеме, когнитивна лингвистика, српски језик.
\end{abstract}

1. Предмет и ичиљеви рада. Предмет нашег рада је непотпуна падежна синонимија, коју ћемо сагледати из угла когнитивне лингвистике. За разлику од већине истраживача, који су настојали да попишу и опишу одређену групу падежних синонима, ми ћемо ову појаву покушати да објаснимо посматрајући неколико типичних случајева. Падежна синонимија спада у семантичко-синтаксичку синонимију (Поповић 1964: 77).

Овај рад надовезује се на наше испитивање падежа и предлошко-падежних конструкција (ППК) са квалитативним значењем (Марковић 2016). У делу рада у ком је анализа била усмерена од садржаја ка форми полазили

*aleksandra.markovic@isj.sanu.ac.rs

*** Рад је настао у оквиру пројекта Лингвистичка истраживања савременог српског књижевног језика и израда Речника српскохрватског књижевног и народног језика САНУ (бр. 178009), који у целини финансира Министарство просвете, науке и технолошког развоја Републике Србије. 
смо од сликовних схема као основног критеријума класификације и тај нам је критеријум омогућио да појаву падежне синонимије сагледамо и објаснимо из новог угла, а помогао нам је и да схватимо због чега су у неким случајевима два падежа синонимна, док у другим, наоко сличним случајевима, нису.

2. Досадашња проучавања падежне синонимије у српском језику. Падежна синонимија била је предмет више радова на српском језику. М. Стевановић ју је шездесетих година прошлог века сврстао у оквире синтаксичке синонимије и скренуо пажњу на важност њеног проучавања (Стевановић 1963). Уследиле су затим студије и радови у којима су изучавана конкурентна синтаксичка (најчешће падежна) средства за изражавање истог или сличног реалног садржаја (љ. Поповић (1964), М. Стевановић (1966), Ж. Станојчић (1967), М. Радовић-Тешић (1972-1973; 1976) и др.). У датим истраживањима аутори су се најчешће користили дескриптивним методама. Представићемо укратко истраживања релевантна за наш рад.

2.1. Пре него што је појава синтаксичке синонимије проблематизована и именована, М. Ивић је писала о односу између квалитативног генитива и инструментала (Ивић 1956). У овом раду падежна синонимија се не помиње експлицитно, већ се говори о напоредној употреби поменута два падежа. Ауторка закључује да је она могућа у ређим случајевима, у којима „конкретна ситуација допушта да се истовремено и једнако осећа битност детерминације ... којом се даје карактеристика целине и чињеница да се ради о истицању једног детаља на целини" (1956: 267; истицање према оригиналу), док је, када је важно истаћи само присуство неке појаве, боље употребити инструменталну конструкцију (1956: 268). Размишљање М. Ивић у сагласности је са идејама когнитивне лингвистике. Наиме, ми га тумачимо овако: критеријум одвојивости/неодвојивости дела од целине не може бити схваћен у дословном смислу, већ је пресудан начин изображења. ${ }^{1}$

2.2. М. Стевановић сматра да су непотпуни синтаксички синоними значајнији и сложенији од потпуних ${ }^{2}$ и да постоје напоредо баш захваљујући непотпуној значењској подударности (1963: 89). Овај аутор долази до сличног закључка као М. Ивић. Он наводи примере плавуша с великим црним младежсм на лииу, с тим ожиљком на врату остала је лепотица, у којима се инструментал не би могао заменити генитивом, и закључује да ће се генитив употребити онда када желимо да окарактеришемо целину неким њеним интегралним делом, док ће се инструментал употребити када се жели истаћи „посебна упадљивост и одвојеност тога дела од целине...” (51991: 458).

И ово размишљање је сагласно са когнитивном лингвистиком - однос између целине и њених делова може се посматрати на више начина.

2.3. Љ. Поповић је дефинисао падежне синониме као „падежне синтагме са детерминативним деловима различитог склопа које се у извесном језику, дијалекту или говору појединца наизменично употребљавају за описивање

\footnotetext{
${ }^{1} \mathrm{O}$ томе шта се подразумева под тим појмом в. т. 3 овог рада.

${ }^{2}$ Потпуни су, на пример, инфинитив и конструкција да + презент; њихова значењска подударност најчешће доводи до потискивања једног синонима (1963: 89).
} 
истог реалног садржаја" (1964: 73, истакла - А. М.). ${ }^{3}$ Он разликује падежне синтагме потпуне и непотпуне синонимности. Првима се исти реални садржај описује на истоветан начин (бојати се некога || бојати се од некога) (1964: 73), док се другима описује „исти реални садржај доживљен на неподударне, али сличне начине" (1964: 74; истакла - А. М.). Како аутор истиче, исти реални садржај сагледан је код сваког синонима на другачији начин, а ти начини међусобно су сагласни; суштинско значење, које потиче од везаности за исти реални садржај, једнако је код свих синонима. Уп.:

„Узети у целини, чланови једне везе падежних синтагми непотпуне синонимности пружају слику могућих доживљавања датог реалног садржаја. Ова категорија падежних синонима заснива се, дакле, на могућности да се код извесних реалних садржаја веза њихових делова доживи на неколико начина ... За падежне синтагме непотпуне синонимности битан је психолошки момент, који се остварује у границама језичких могућности" (1964: 75; истакла - А. М.).

У речима Љ. Поповића за наш рад кључно је следеће: указивање на могућност да се исти реални садржај доживи на више начина, као и да се однос, веза делова одређеног реалног садржаја сагледа различито.

2.4. М. С. Лалевић, у неком смислу слично Љ. Поповићу, каже да се синтаксичка синонимика понекад „ослања на саму везу као карактеристичну особеност синтаксичке синонимике, у којој су исти граматички елементи, али се различно везују" (1973: 388-389; истакла - А. М.).

3. Како нам когнитиивна лингвисииика може йомоћи у разумеваюу йојаве йадежне синонимије? У претходном делу излагања представили смо размишљања аутора који су се бавили падежном синонимијом у српском језику и настојали да објасне ту појаву на неки начин. Осим што су се ослањали на семантику и синтаксу падежа, неки од њих су разматрали и нешто што су назвали $\bar{u} с и х о л о ш к и м ~ м о м е н \overline{и о м ~ к о ј и ~ б и ~ м о г а о ~ д а ~ о б ј а с н и ~ п о ј а в у ~ п а д е ж-~}$ них синонима. Иако су поменута истраживања спроведена у оквиру традиционалног и структуралистичког приступа, у неким сегментима, на које смо скренули пажњу, могу се посматрати као врло блиска когнитивнолингвистичким. Наша размишљања у овом раду на трагу су тих размишљања.

У когнитивној семантици значење се посматра као концептуализација (или когнитивна обрада) (Ланакер 1991: 1; 2009: 6). Значење језичких израза не чини само појмовни садржај већ и construal, начин изображења ${ }^{4}$ (Ланакер 2000: 5), па је за лингвистичку семантику кључна наша способност да исту сцену уобличимо на различите начине. Свако изображење има више димензија, а једна од њих је степен истакнутости елемената које садржи (2009: 6).

\footnotetext{
${ }^{3}$ Важно је напоменути да у овом свом раду Љ. Поповић под падежном синтагмом (термином који у својој Синтакси касније не користи; в. Станојчић/Поповић ${ }^{142012)}$ подразумева падеж / предлошко-падежну конструкцију, као и реч која се њима допуњава или одређује (1964: 73, у фусноти), за разлику од М. Стевановића, код кога тај термин нема јасан појмовни садржај (некад се односи на сам падеж, некад на ППК, дакле на конструкцију која не потпада под дефиницију синтагме). Више о том проблему в. у Стипчевић/Самарџић (2003: 141-144).

${ }^{4}$ Предлог да се Ланакеров термин construal преведе као изображење дају К. Расулић и Д. Кликовац (2014: 205).
} 
Постоје разни типови истакнутости, а за наш рад је релевантна организација по принципу трајектор/оријентир (trajector/landmark).

Најпре ћемо рећи нешто о значењу падежа као релационих израза, затим о сликовним схемама које стоје у основи појединих падежа и предлошко-падежних конструкција и показати како се на основу сликовних схема може објаснити падежна синонимија.

3.1. Падежи као релациони изрази. У тумачењу падежа и њима означених односа у светлу когнитивне лингвистике поћи ћемо од речи Р. Ланакера, који каже: „Когнитивни домен на ком се заснива семантички опис [падежног облика] јесте схематизована концепција одређеног односа" (1991: 235). Дакле, падежи имају релациону природу, означавају односе међу појмовима (баш као и предлози и ППК, чији су део). Релационим изразима обично се изражава асиметрија којом се један од учесника издваја као онај који се лоцира или описује. То је први фокални учесник, трајектор (енгл. trajector). Обично постоји и други фокални учесник, оријентир (енгл. landmark) (Ланакер 2009: 8-9). У српском језику у когнитивнолингвистичким истраживањима уместо ових термина претежно се користе термини објекат локализације (ОЛ) и локализатор (Л), које је увела Д. Кликовац и које ћемо и ми користити у овом раду $\left({ }^{2} 2006: 20\right){ }^{5}$

Падежну синонимију разматраћемо на примерима падежа и предлошко-падежних конструкција с квалитативним значењем, и то оних у атрибутској функцији (нпр. човек йлавих очију $\|$ човек са йлавим очима). ${ }^{6}$

Најпре ћемо видети како се појмови ОЛ и Л могу идентификовати у конструкцијама које су предмет нашег рада, другим речима - како треба тумачити однос између управног појма и појма означеног падежним обликом, односно ППК.

Будући да посматрамо конструкције које чине управна именица и њена одредба у неком падежу, односно ППК, управном именицом означен је онај учесник односа који се одређује или описује. Како Ланакер истиче, учесник који се лоцира или описује јесте први фокални учесник (2009: 8-9), у нашој терминологији ОЛ. Други учесник у односу јесте онај на основу ког се први лоцира/описује, Л, изражен падежним обликом или ППК.ㄱ Дакле, као ОЛ посматрамо појам означен управном именицом, који се описује, а као Л

\footnotetext{
${ }_{5}^{5}$ Д. Кликовац примећује да је термин објекат локализације подеснији од термина трајектор јер се не мора односити на предмет у покрету (22006: 20). С обзиром на природу појмова означених конструкцијама које посматрамо, и за наш рад су погоднији поменути термини.

${ }^{6}$ Примере преузимамо из рада Марковић 2016.

${ }^{7}$ Неки слушаоци током излагања овог реферата сматрали су необичном чињеницу да се као локализатор посматра део тела. Дефинишућу особину фигуре (у нашој терминологији ОЛ), Талми као основну, издваја чињеницу да има непознате просторно-временске одлике које треба утврдити; за разлику од тога, основу (Л у нашој терминологији) дефинише то што се јавља као референтни ентитет, с познатим одликама, које могу одредити оно што је непознато код фигуре (Л) (више о томе в. Талми 2000: 315). Уколико се из просторно-временског домена пребацимо у апстрактнији домен, какав је и описивање, јасно је да се могу применити исти принципи. Уз то, и у овом случају може се приметити да се синтаксичка и семантичка структура разилазе, како то у вези са зависним клаузама примећује Д. Кликовац - ситуација означена синтаксички зависном клаузом јавља се као оријентир у семантичком смислу за ситуацију означену управном реченицом (више о томе Кликовац 2017: 7; Талми 2000: 321 и даље). Уз то, прихватљивост орга-
} 
појам означен именичком јединицом у зависном падежу или ППК, помоћу кога се описује.

3.2. Сликовне схеме. У питању је један од основних теоријских конструката у когнитивној семантици. Теорију сликовних схема засновали су М. Џонсон (1987) и Џ. Лејкоф (1987). Џонсон истиче да су за нашу способност разумевања суштински важне сликовне схеме (Џонсон 1987: 18). Оне настају на основу телесног искуства - наше чулне интеракције са околином, кретања у њој и руковања разним предметима - и омогућавају нам да искусимо свет и да га разумемо као кохерентну целину. Схеме су препојмовне, апстрактне природе (1987: 18-22; 31). Схема је образаи, облик или правило које се понавља у радњама које обављамо, нашим доживљајима и појмовима (1987: 30). Важност ових схема за разумевање (а самим тим и за језик помоћу ког се изражавамо) јесте у томе што су све засноване на телесном искуству и толико свеприсутне у нашем свакодневном животу да се њихов значај често превиђа у размишљању о значењу и разумевању (1987: 31). Џонсон издваја СХеМе САДРЖАТЕЉА, СИЛЕ, РАВНОТЕЖЕ, ПУТАњЕ, ЦИКЛУСА, ВЕЗЕ И Др. (1987: 21, 42, 74 и даље). Лејкоф додатно разматра и неке схеме које Џонсон помиње, али о њима не говори детаљно (на пример, схему дЕо-ЦЕЛИНА, ИЗВоР-ПУТАњА-цИљ 1987: $273-274,275)^{8}$

СХема САДРЖАТЕљА У вези је с веома застуПљенИм теЛесним искуством са садржавањем и ограниченошћу - своја тела доживљавамо као сАдРЖАТЕљЕ, аЛИ и Као САДРЖАНЕ ОБЈЕКТЕ (исто, 21). СХемУ чИНе следећи еЛеменТИ: УНУТРАШњОСТ, ГРАНИЦА и СПОљАШњОСТ (Лејкоф 1987: 272). Ова схема метафорично се преноси на друге домене, па тако као САДРЖАТЕљЕ концептуализујемо многе апстрактне појмове - време, стање, положај, језик и др. (о овој схеми детаљно говори Кликовац ${ }^{2} 2006$ ). Схеми САДРЖАТЕљА Поклоњено је доста пажње у когнитивнолингвистичким истраживањима.

О схеми ДЕО-цЕЛИнА говори Лејкоф. И она има основу у телесном искуству: ми смо бића са деловима које можемо да контролишемо. Читавог живота свесни смо целине свог тела и његових делова. За наше сналажење у свету важно је и то што смо свесни да и други предмети имају исту структуру. Схема има следеће елементе: целинА, дЕЛови, конФигурАцијА; асиметрична је: ако је А део Б, Б није део А. Постојање целине условљено је постојањем делова, као и тиме да делови морају бити у одређеној конфигурацији.У типичном случају делови су „суседни”. И ова схема може се применити на друге домене: брак схватамо као стварање породице (целине), са супружницима као деловима; самим тим, развод се доживљава као подела (Лејкоф 1987: 273-274). Као целине схватамо и пропозиције, са предикатом и аргументима као деловима (1987: 285) и сл.

низације по принципу фигуре и основе (трајектора и оријентира) може да варира у зависности од предлога (Херсковиц 1986: 38; Тиринг 2011: 247).

${ }^{8}$ Иако је сама онтологија сликовних схема од настанка теорије до данас често била предмет преиспитивања (в. нпр. Ћенки 1995), схеме које су за наш рад релевантне спадају у оне око којих постоји већи консензус - схеме САДРЖАТЕљА, ВЕЗЕ и ДЕО-ЦЕЛИНА угЛавном издвајају сви аутори; међутим, није свима поклоњена подједнака пажња. 
И схема ВезЕ заснована је на телесном искуству - прва веза јесте пупчана врпца која нас спаја с мајком. Пошто се та веза пресече, ступамо у друштвене везе. Како Џонсон истиче, комбинација наших чулних могућности и наше перцептивно уочљиве околине доводи до великог, испреплетаног комплекса конкретних и апстрактних веза (1987: 117). Најпре, уочавамо парове физичких предмета (нпр. две даске прикуцане једна за другу), када постоји просторна суседност и близина повезаних предмета, као и конкретна веза. Осим физичких и просторних веза, дете током развоја стиче искуство и са временским и узрочним везама. Схему чине два ентитета, А и Б, као и веза међу њима. У типичном случају, ентитети су у просторној близини. У проширеним случајевима, реч може бити и о више повезаних ентитета, као и о просторно и временски раздвојеним/несуседним ентитетима (1987: 118). Џонсон истиче, а то је за наш рад веома важно, да постоје два основна типа метафоричких интерпретација схеме ВЕзЕ: апстрактном се може схватити или сама веза или ентитети коју у њу улазе. Веза се може схватити као апстрактна у функционалним целинама, које Џонсон издваја као један случај узрочне повезаности делова или ентитета (неки предмет не мора бити заиста повезан са другим, а ипак могу постати повезани на основу свог односа у функционалној целини) (1987: 118-119). У метафоричком смислу, социјалне и међуљудске односе често схватамо на основу веза - успостављамо везе и кидамо друштвене везе (Лејкоф 1987: 274).

На први поглед се уочава да између схеме дЕО-цЕлинА и схеме вЕЗЕ, У оном виду у ком их сагледавају Лејкоф и Џонсон, постоје извесна преклапања. Схему везе чине (типично) два (одвојена) ентитета, као и веза међу њима; међутим, како истиче Џонсон, могу се повезивати и делови. Уз то, веза се може схватити метафорично, па се и функционални склопови посматрају као целине (чак и делови који нису суседни постају повезани припадањем истом склопу или целини). Иако то код схеме вЕзЕ није експлицирано, примећујемо да оно што чине повезани ентитети мора да резултира неком врстом целине. Чак и примери метафоричких схема које Лејкоф наводи су слични: за схему дЕо-цЕлинА наводи се пример брака (целине, са супружницима као деловима), док се за схему везЕ наводе социјални и међуљудски односи. ${ }^{9}$

Наш је закључак да изворно одређење поменуте две схеме није сасвим прецизно. И самој схеми вЕзЕ поклоњено је, наш је утисак, најмање пажње у когнитивнолингвистичким истраживањима, а кад се наводе примери метафоричних веза, нагласак се обично ставља на сам однос или релацију (в. нпр. како Лејкоф семантичке односе између аргумената у пропозицији или граматичке односе посматра као схему ВEзЕ (1987: 285, 290). Наше је мишљење да

\footnotetext{
${ }^{9}$ Питање које је за нас важно и на које засад немамо одговор јесте и однос схеме вЕзЕ и схеме CПAJAњA (MERGING). Ово питање задире и у онтологију сликовних схема - ако се у обзир узме могућност да се схеме реализују у статичком или динамичком облику, ове две схеме могу се посматрати као варијанте једне - СПАЈАњЕ може бити процес који резултира вЕзом (о статичној/ динамичној природи сликовних схема и вези те идеје с оним што Лејкоф назива трансформацијама сликовних схема (1987: 110 и даље) говори Ћенки (1995: 6-7)).
} 
схема ВЕЗЕ није разЛичита од онога што се назива односом ПРАЋЕњА (више о овом односу у литератури в. Марковић 2016: 241 и даље).

Сликовне схеме могу нам пружити дубљи увид у семантику падежа. ${ }^{10}$ Тако се квалитативни генитив може посматрати као падеж који подразумева схему дЕо-цЕЛинА. Квалитативни инструментал имплицира вЕзу њим означеног појма с појмом означеним управном именицом (како је показало наше истраживање, овај падеж омогућава изражавање повезаности између појмова различите природе; однос је такав да намеће мања ограничења у повезивању појмова него што је то случај са квалитативним генитивом и локативом). Квалитативна значења локатива која посматрамо у овом раду везана су за схемУ САДРЖАВАњА.

3.3. Сликовне схеме и падежна синонимија. Рекли смо да је номиналом у падежу или ППК с квалитативним значењем кодиран Л, док је управном именицом кодиран ОЛ. Уколико се са формалног терена, са терена падежних облика, померимо на природу односа између ОЛ и Л, у овом случају на сликовне схеме у основи падежних односа, моћи ћемо да загледамо испод површине и да разумемо због чега, на пример, квалитативни генитив у неким случајевима улази у однос непотпуне синонимије са квалитативним инструменталом, а у неким случајевима са квалитативним локативом. На пример, квалитативни генитив и квалитативни локатив непотпуни су синоними када су њима изражене такве инхерентне особине као што су величина, облик, боја и стил (кугле разних боја и слике у живим бојама), али не и онда када су у питању висина, дебљина и обим (сталажице неједнаке висине, *сталажице у неједнакој висини; вочтаница необичне дебљине, али *вочтаница у необичној дебљини).

Наше истраживање падежа и ППК с квалитативним значењем (Марковић 2016) показало је да је у квалификовању доминантан однос између целине и њених делова. Више од половине анализираних примера у нашем раду (а било их је око 1500) указивало је на квалификовање целине неким делом. У овој тачки размотрићемо како се може изразити исти реални садржај. Видећемо да се критеријум неодвојивости, односно интегралности, који се понекад узима као релевантан за кодирање односа квалитативним генитивом, не може узети као једини. Чињеница да су неки појмови реално неодвојиви од целине није довољна за њихово изражавање квалитативним генитивом. То

\footnotetext{
${ }^{10}$ Д. Кликовац истиче да су предлози ,jedno od osnovnih sredstava pomoću kojeg se slikovne sheme izražavaju u jeziku" (22006: 26). Ми додајемо да и падежни облици (с предлозима или без њих) служе у те сврхе. Посебно је питање да ли се, у случају када је реч о предлошко-падежној конструкцији, може говорити о једној или двема сликовним схемама и у какав однос те схеме улазе. Нама се чини да предлог и падеж исказују посебне сликовне схеме. Д. Кликовац то експлицитно не констатује, али сматра да конструкција $y$ + акузатив ,označava S[adržatelj] u kome $\mathrm{S}$ [adržani]O[bjekat] zauzima mesto - tako što u njega ulazi (ako je biće) ili biva u njega unesen (ako je predmet)" (22006: 204, истицање према оригиналу). Дакле, овде би се могло говорити о наношењу (superimposition) схеме ПуТАњЕ на схему САДРЖАТЕљА ИЛИ о динамичној схеми, налик на ону о којој говоре Мендлерова и Кановас: ови аутори сматрају да су просторни примитиви путање, усмереног кретања и садржатеља коцкице којима се гради сликовна схема коју називају ствАР У САДРЖАТЕљУ (THING INTO CONTAINER); наиме, сликовне схеме према овим ауторима јесу појмовне представе које описују догађаје (в. Мендлер/Кановас 2014: 9-10).
} 
значи да на формално кодирање (самим тим и на појаву падежне синонимије) утиче и начин изображења односа између ОЛ и Л. Посматраћемо четири случаја: најпре ћемо посматрати онај када је ОЛ човек, а Л неки део тела (т. 3.3.1), а затим случај када је ОЛ човек, а Л неки апстрактан појам (т. 3.3.2); трећи случај тицаће се предмета као ОЛ и неког његовог дела као Л (т. 3.3.3), а четврти оног када је Л инхерентна особина предмета као ОЛ (3.3.4).

3.3.1. Чак и у случајевима када је ОЛ човек, а Л неки део тела, однос између њих може се сагледати на више начина, а сматрамо да су управо ти начини у вези с постојањем односно непостојањем падежне синонимије. Квалитативни генитив и инструментал најчешће улазе у однос непотпуне синонимије када је Л део тела као што су очи и космати делови главе (брада, бркови, коса): човек плавих очију ${ }^{11} \|$ деиее са великим очима; човек дугих бркова \| $\bar{u} и \bar{u}$ са (дугим) брковима. Међутим, када су у питању такви „делови” као што су младежи, пеге, боре, бубуљице, ожиљци - изостаје могућност употребе квалитативног генитива - лингвисти с са бубуљицама; дакйилографкиња с иегама на носу: ти делови не могу да се посматрају као интегрални делови тела, већ као појмови пратиоци појма означеног управном именицом. Због тога се тај однос може посматрати само као однос ВЕЗЕ и изразити искључиво инструменталом (с тим у вези в. размишљања М. Ивић и М. Стевановића у т. 2.1 и 2.2 овог рада). Укратко, појаву непотпуне падежне синонимије између квалитативног генитива и инструментала објашњавамо могућношћу да се однос између ОЛ и Л сагледа на више начина - и као однос ДЕО-ЦЕЛИнА, али и као општији однос ВЕзЕ; Л се у првом случају концептуализује као интегрални део (и кодира квалитативним генитивом), у другом као Појам ПрАТиЛАЦ (кодиран квалитативним инструменталом). Када такве могућности нема, изостаје и синонимија ова два падежа.

3.3.2. Када је ОЛ човек, а Л неки апстрактан појам (узраст, године, тежина, висина, поглед и сл.), ситуација се мења. Као што је то и више пута истицано у литератури (в. нпр. Ивић 1956: 261), инхерентне појаве/особине не могу се изразити инструменталом. Наша грађа у раду Марковић 2016 показала је да се период живота, године јављају као доминантна инхерентна појава у квалификовању живих бића, као и то да се могу концептуализовати на два начина - као апстрактан део, када се кодирају квалитативним генитивОМ (ИНХЕРЕНТНЕ ПОЈАВЕ СУ ПОСЕСУМИ) (човек средњих година, деца школског yзраста) или као метафорички САДРЖАТЕљ за човека, кодиран ППК $y+$ локатив (људи у (млађим) годинама, дете у школском узрасту). Отуда и синонимија квалитативног генитива и локатива.

3.3.3. Када је ОЛ неки предмет (као артефакт), а Л неки део тог предмета, такав Л чешће је концептуализован као појам пРАтилАц и кодиран ППК $c(a)+$ И него као инхерентан део, према подацима из наше грађе. Квалитативни генитив улази у однос непотпуне синонимије са инструменталом у

11 За квалитативни генитив карактеристичан је обрнут однос посЕСоРА и ПосЕСумА: посесивним генитивом кодиран је посесор (кућа мога брата), док је квалификативним генитивом изражен посесум (жена лепих очију). На ову чињеницу указао је још Ђ. Даничић (1858: 53). Више о овом питању в. Марковић (2016: 77-79). 
примерима типа хаљине широких рукава $\|$ хаљине са широким рукавима. Међутим, неки делови не могу се изразити генитивом: буре са гвозденим обручима, али не и *буре гвоздених обруча. Ми смо то објаснили чињеницом да се однос између бурета и обруча може сагледати као однос вЕзЕ, али не и као однос дЕО-цЕЛинА. Наиме, Л (гвоздени обручи) не схвата се као инхерентан део, већ је нагласак на његовом присуству, постојању. ${ }^{12}$

3.3.4. Када је ОЛ предмет, а Л инхерентна особина тог предмета (нека од особина условљених природом појма: величина, висина, дебљина, обим, боја и сл.), таква особина најчешће се концептуализује као интегрални део и бива изражена квалитативним генитивом: кугле разних боја, клупе неправилна облика, лирска песма необичне лепоте, замак невеликих размера, возила европског стила. Неке од особина могу се изразити и квалитативним локативом: слике у живим бојама, украси у облику брода, кућа у шпанском cmилу. Поставља се питање због чега је то могуће само за неке инхерентне особине, али не за све - због чега наспрам воштаница необичне дебљине, сталажице неједнаке висине, прозори малог обима немамо синониме са зависним номиналом у квалитативном локативу (*воштаница у необичној дебљини, *сталажице у неједнакој висини, *прозори у малом обиму)? Наше објашњење заснива се на чињеници да се неке инхерентне особине, осим као дЕлови, могу концептуализовати и као метафорички САДРЖАТЕљи (величина, облик, боја и стил), док за неке друге то није могуће (висина, дебљина, обим).

Прецизно објашњење за ову појаву налазимо у истраживању Д. Кликовац, која говори о облику као метафоричком САДРЖАТЕљУ и указује на то да је облик предмета дефинисан његовом спољном површином, која се метафорички схвата као љУскА или ОмотАч у ком се предмет налази (22006: 164). Осим облика у ширем смислу, као метафорички САдРЖАТЕљи јављају се стил, као и боја ${ }^{13}$ и величина (у овом случају, облик се не односи на изглед, већ на квантитативни аспект одређеног ентитета) (22006: 164-167).

Међутим, објашњење захтева и питање због чега се као метафорички садржатељи не могу концептуализовати и висина, дебљина и обим. Претпостављамо да разлог лежи у томе што се висина, дебљина и обим (обим у неким значењима) везују за једну димензију (замишљамо их као линију, праву или кружну), која се не може концептуализовати као САдРжАТЕљ.

4. Закључак. Појава падежне синонимије била је предмет многих радова на српском језику, што сведочи о томе колико је ова тема инспиративна за лингвисте. Неки од аутора (Ивић, Стевановић, Поповић) настојали су да, осим пописа и описа падежних синонима, пруже и објашњење специфичности употребе појединих падежних облика. Наше је истраживање на том трагу.

\footnotetext{
${ }^{12}$ Слично објашњење налазимо и код Л. Јанде. Она, наиме, примећује да је оно што омогућава да се делови неког учесника представе као додаци који га прате у односу праћења прекривање схеме дЕо-целина: We bought a couch with a high back (Јанда 1993: 184).

${ }^{13}$ Како истиче Д. Кликовац, ово је маргиналнији случај, јер је облик „u prototipičnom slučaju stvar poimanja putem svih (ili bar nekoliko) čula, ali, u marginalnijim manifestacijama, može biti stvar samo vizuelnog utiska" (22006: 165).
} 
Занимало нас је шта лежи испод површине језичке форме, другим речима, које су то когнитивне појаве које леже у основи падежне синонимије.

Пошли смо од идеје да се исти реални садржај (у нашем истраживању, у питању је однос између појма означеног управном именицом и оног означеног именичком јединицом у зависном падежу или ППК) може сагледати на различите начине, самим тим, и изразити различитим падежима или ППК. Падежима се (као и предлозима) означавају односи, спадају у релационе изразе, а релационим изразима изражава се асиметрија: један члан односа издваја се као онај који се лоцира (ако је реч о просторном домену; пошто смо се ми бавили квалификацијом, говоримо о описивању) или описује, ОЛ, и то на основу другог члана, Л. У конструкцијама које чине управна именица и њена одредба, ОЛ је појам означен управном именицом, а Л појам означен именичком јединицом у зависном падежу или ППК.

Однос између ОЛ и Л може се концептуализовати на више начина. На основу анализе шире грађе, која због ограниченог обима овог рада није могла да буде представљена, закључили смо да се појединим падежима са квалитативним значењем изражавају различите сликовне схеме. Посматрали смо квалитативни генитив, инструментал и локатив. За квалитативни генитив карактеристична је схема ДЕО-цЕЛИНА, за инструментал схема ВЕЗЕ, а за локатив - САДРЖАТЕЉА.

Падежну синонимију објаснили смо могућношћу да се однос између ОЛ и Л сагледа на више начина: синонимија квалитативног генитива и инструментала постоји када се Л може концептуализовати и као инхерентни дЕО (изражен генитивом) и као појам ПРАтилАЦ (изражен инструменталом): човек дугих бркова || човек са (дугим) брковима; хаљине широких рукава $\|$ хаљине са широким рукавима. Када такве могућности нема, изостаје и синонимија: лингвисти са бубуљицама, буре са гвозденим обручима. Синонимија између квалитативног генитива и локатива је могућа онда када се појам Л може концептуализовати или као инхерентан део (или, метафорично, инхерентна особина) (човек средњих година, кугле разних боја) или као метафорички САДРЖАТЕљ (људи у (млађим) годинама, слике у живим бојама). Међутим, неке Л није могуће концептуализовати као САДРЖАТЕљЕ (*воштаница у необичној дебљини), самим тим, ни изразити квалитативним локативом.

\section{ЛИТЕРАТУРА}

Даничић 1858: Ђ. Даничић, Србска синтакса I, Београд: Државна штампарија.

Ивић 1956: М. Ивић, Однос између квалитативног генитива и квалитативног инструментала, Наш језик, VII/7-10, 260-269.

Ивић 1957-1958: М. Ивић, Систем предлошких конструкција у српскохрватском језику, Јужнословенски филолог, XXII, 141-166.

Јанда 1993: L. A. Janda, A Geography of Case Semantics. The Czech Dative and the Russian Instrumental, Berlin - New York: Mouton de Gruyter. 
Кликовац 22006: D. Klikovac, Semantika predloga. Studija iz kognitivne lingvistike, Beograd: Filološki fakultet.

Кликовац 2017: Д. Кликовац, Како проста реченица може бити сложена (О подели реченица „по саставу”), Кьижевност и језик, LXIV/1-2, 1-24.

Лалевић 1973: Прилог из синтаксичке синонимике, Јужнословенски филолог, XXX/1-2, 387-390.

Ланакер 1991: Ronald W. Langacker, Concept, Image and Symbol. The Cognitive Basis of Grammar, Berlin - New York: Mouton de Gruyter.

Ланакер 2000: Ronald W. Langacker, Grammar and Conceptualization, Berlin - New York: Mouton de Gruyter.

Ланакер 2009: Ronald W. Langacker, Investigations in Cognitive Grammar, Berlin - New York: Mouton de Gruyter.

Лејкоф 1987: George Lakoff, Women, Fire, and Dangerous Things. What Categories Reveal about the Mind, Chicago-London: The University of Chicago Press.

Марковић 2016: Падежи и предлошко-падежне конструкиије са квалитативним значењем у савременом српском књижевном језику (семантичко-синтаксичка анализа) (необјављена докторска дисертација, Београд: Филолошки факултет).

Мендлер/Кановас 2014: J. M. Mandler, C. P. Cánovas, On defining image schemas, Language and Cognition, Vol. 6, Issue 4, 1-23.

Поповић 1964: Љ. Поповић, Падежна синонимика у језику Вука Стеф. Караџића, Наш језик, XIV/2-3, 73-129.

Радовић Тешић 1972-1973: М. Радовић-Тешић, Предлог код уз генитив глаголских и других апстрактних именица у функцији одређивања времена и његове семантичко-синтаксичке опозиције, Наш језик, XIX/4-5, $228-255$.

Радовић Тешић 1976: М. Радовић-Тешић, Предлог код с генитивом неправих (конкретизованих) глаголских именица, Наш језик, XXII/3, 101-115.

Расулић/Кликовац, ред. 2014: К. Расулић, Д. Кликовац, Језик и сазнање. Хрестоматија из когнитивне лингвистике, Београд: Филолошки факултет.

Станојчић 1967: Ž. S. Stanojčić, Jezik i stil Iva Andrića (funkcije sinonimskih odnosa), Beograd: Filološki fakultet Beogradskog univerziteta.

Станојчић/Поповић ${ }^{142012: ~ Ж и в о ј и н ~ С т а н о ј ч и ћ, ~ Љ у б о м и р ~ П о п о в и ћ, ~ Г р а-~}$ матика српског језика за гимназије и средюе школе, Београд: Завод за уџбенике.

Стевановић 1963: М. Стевановић, Синтаксичка синонимика, Књижевност и језик, X/2, 81-95.

Стевановић 1966: М. Стевановић, Генитивне синтагме с предлогом код и неке њихове опозиције, Наш језик, XV/3-4, 158-179.

Стевановић 51991: М. Стевановић, Савремени српскохрватски језик (Граматички системи и књижевнојезичка норма), књ. II, Синтакса, Београд: Научна књига. 
Стипчевић/Самарџић 2003: Б. Стипчевић, Т. Самарџић, Терминологија синтаксе падежа Михаила Стевановића, Научни састанак слависта у Вукове дане, 32/3, 140-156.

Талми 2000: L. Talmy, Toward a Cognitive Semantics, Vol. 1: Concept Structuring Systems, Cambridge/London: The MIT Press.

Тиринг 2011: M. Thiering, Figure-Ground Reversals in Language, Gestalt Theory, Vol. 33/3-4, 245-276.

Ћенки 1995: A. Cienki, Some Properties and Groupings of Image Schemas, in: H. Verspoor, K. Dong Lee, E. Sweetser (ред.), Lexical and Syntactical Constructions and the Construction of Meaning: Proceedings of the Bi-annual ICLA Meeting in Albuquerque, Amsterdam/Philadelphia: John Benjamins Publishing Company.

Херсковиц 1986: A. Herskovits, Language and spatial cognition. An interdisciplinary study of the prepositions in English, Cambridge: Cambridge University Press.

Џонсон 1987: M. Johnson, The Body in the Mind. The Bodily Basis of Meaning, Imagination, and Reason, Chicago-London: The University of Chicago Press.

Aleksandra M. Marković

\section{THE COGNITIVE-LINGUISTIC ASPECT OF NEAR-SYNONYMY IN SOME CASE FORMS WITH QUALITATIVE MEANING IN THE SERBIAN LANGUAGE}

Summary

The subject of this paper is the phenomenon of near-synonymy between some case forms with qualitative meaning in Serbian, namely between: 1. the qualitative genitive and instrumental and 2. the qualitative genitive and locative. We searched for the answers to two questions: what is it that gives rise to this kind of near-synonymy and why is it the case that two case forms are synonymous in one situation, while in the other, which is similar to it, they are not.

Our search for the answers to these questions imposed the need to take a look below the surface of the language form and to find the cognitive mechanisms which are fundamental for the synonymy between case forms. We assigned an image-schema to each case form we considered: the image-schema relevant for the qualitaitve genitive is the PART-WHOLE SCHEMA, for the instrumental the LINK schema, and the CONTAINER schema for the qualitative locative. According to our analyses, the possibility that the relation between the trajector and the landmark can be viewed in two or three different ways gives rise to the near-synonymy of case forms.

Key words: near-synonymy, case forms and prepositional case constructions with qualitative meaning, image schemata, cognitive linguistics, the Serbian language. 